\title{
How Neandertals Inform Human Variation
}

\author{
Milford H. Wolpoff* \\ Department of Anthropology, University of Michigan, Ann Arbor, MI 48109-1092
}

\author{
KEY WORDS Neandertal; race; subspecies; human variation
}

\begin{abstract}
Since their first discovery, Neandertals have served as an out-group for interpreting human variation. Their out-group role has changed over the years because in spite of the fact that Neandertals are the most abundant of all fossil remains (or perhaps because of this) their interpretation is the most controversial of all human fossils. Many believe them to be a different, albeit human-
\end{abstract}

Modern humans, meaning living humans and their immediate ancestors, vary extensively. Modernity means different things in different places, but modern human variation is limited in that the one thing it usually does not mean is Neandertal. However, this has not always been the case. Historically, the interpretation that there was a Neandertal race (the term race is not used in quotations when referring to human races, even though many authors follow this convention to indicate their belief that human races do not exist. The author is sympathetic to this view; yet in the biological world races do exist for some species, and the author does not want to imply that the race concept itself is invalid. The issue of human races is quite complex, which is why the topics addressed in this conference are current) first meant that Neandertals fell within this variation, whereas the interpretation that there was a Neandertal species meant falling outside of it. Later, the issue became more complex with the recognition that ancient races might be expected to differ more than modern populations from different geographic regions do because of subsequent evolutionary changes and expanding population size. The difficulty with the Neandertal issue increased with the recognition that the human variation is not racial. Discussions of a Neandertal race ultimately address how we view human racial variation in an evolutionary context.

In this article, the history of the Neandertal out-group for human variation is cast in how Neandertals have played the role of "other;" how Neandertals have been interpreted as an anatomical ancestor, and as a genetic ancestor. The role of Neandertals in understanding human variation is complex because of the combination of anatomical difference, restricted gene flow with contemporaries, and the temporal difference between Neandertals and modern humans.

\section{NEANDERTALS INFORM HUMAN VARIATION IN THEIR ROLE AS “OTHER”}

The issue of whether there once existed a Neandertal race began as an evolutionary question, but was addressed with a phenetic answer (Wolpoff and Caspari, 1997). The Feldhofer Neandertal was first described as a species by King (1864) because of how different from liv- like species, but recent genetic evidence supports anatomical interpretations indicating that interbreeding with other humans was an important aspect of human evolution. The combination of anatomical difference and restricted gene flow between populations suggests the possibility that Neandertals may have been a true human race. Am J Phys Anthropol 139:91-102, 2009. @ 2009 Wiley-Liss, Inc. ing humans it appeared to be; King, in fact, first wrote "so closely does the fossil cranium resemble that of the Chimpanzee, as to lead one to doubt the propriety of generically placing it with Man." In the half century following the Feldhofer discovery evolution was rejected by many scientists. A number of them found the Neandertal to be somewhat less different than King described, actually no different in type from other human races, although more primitive. Ludwig Wilser named this "vintage" European race "Homo primigenius," and Neandertals from Feldhofer, and later from the Croatian site of Krapina, were key members of it. Wilser was a physician with bizarre racial theories of Aryan superiority (Aryans, in fact all of humanity, originated in preglacial Sweden, according to Wilser).

It is often suggested that the early interpretations of Feldhofer (and other human fossils) were constrained by a lack of appreciation of human antiquity (e.g. van Riper, 1993; Sackett, 2000), but in fact Johann Carl Fuhlrott (the local naturalist who recognized the Feldhofer skeleton as a human, not a bear as first thought) and Hermann Schaaffhausen (the medical doctor and anthropologist who first evaluated the skeleton) acknowledged the association with fragmentary remains of extinct animals and regarded the Neandertal as an ancient human fossil (Zängl, 2006, p. 46-47) of diluvial age (Schmitz, 2006, p. 42). Early on, in 1857, Schaaffhausen emphasized that the cranial form was natural (in the sense of not being pathological) but with a low level of development that cannot be found in living races.

This, of course, was before the theory of evolution was published and the absence of the Darwinian framework was a significant impediment. A deeper unresolved theoretical problem played a continuing role-the relation of race and human evolution (Wolpoff and Caspari, 1997).

*Correspondence to: Milford H. Wolpoff, Department of Anthropology, University of Michigan, Ann Arbor, MI 48109-1092, USA. E-mail: wolpoff@umich.edu

Received 26 March 2008; accepted 4 August 2008

DOI 10.1002/ajpa.20930

Published online 18 February 2009 in Wiley InterScience (www.interscience.wiley.com). 
This was especially important in Central Europe, where 19th Century physical anthropology grew rapidly (Henke, 2008) after Feldhofer's discovery, but not necessarily in acceptance of evolutionary theory. Certain of the Central European holdouts against Feldhofer's evolutionary interpretation had considerable influence, such as Rudolf Virchow in Germany who thought the Feldhofer Cave Neandertal skeleton's differences could be explained by pathology (as did Welcker and Vogt). The holdouts were academically powerful; as late as the 1892 Anthropological Congress in Ulm, many of the German experts denied there were any human fossils, especially European ones (Radovčić, 1988).

If Feldhofer was not pathological, or paleontological, could it simply represent another human variety, or race? This was an interpretation found both in Central Europe (see below), and in the west where leading scholars such as Paul Broca did not accept the Neandertal as a true fossil, and a number of others regarded Neandertals as no more than a "primitive race of Homo sapiens"- these include Fraipont, Hamy, and de Mortillet (Henke, 2008). When the key Neandertal discoveries at the Belgian site of Spy were published (Fraipoint and Lohest, 1887), they were interpreted in the racial framework first presented by Quatrefages and Hamy (1882), in which the Canstadt skull (a partially preserved recent human) was used as the basis for postulating a première race fossile that also included the Feldhofer Neandertal.

In Central Europe, Johannes Ranke, a Munich anthropologist, played a key role in developing the idea of a Neandertal race. Ranke became editor of the preliminary reports section of the Archiv für Anthropologie, the journal of the German Society for Anthropology, Ethnology, and Prehistory that was founded in Berlin by Rudolf Virchow. Ranke was a leading authority on racial variation who published on the relation of human fossils and the living races (1896). He was a confirmed monogenist, inheriting what was even then the old Blumenbach anthropological position that all humans were of a single variable type, with only minor variations that reflected different climates, and were linked together by intergradations. Ranke recognized the existence of human races and classified them on the basis of physical characteristics such as head shape, skin color, and hair form. Influenced by Virchow, he believed the human races were unchanged through prehistory, certainly since glacial times, and thought that from the first there were representatives of modern humanity already differentiated into races with differences that were quite minor. Ranke, in fact, contended there were no true fossil races, in the sense of being taxonomically different from living ones, and that Neandertals were human beings, members of the species Homo sapiens because their "characteristic peculiarities do not remove this race from the series of forms already known to us from modern races" (Ranke, 1896). The Neandertal race was a variant of humanity that differs from other variants in ways that human variants differ among themselves.

Soon thereafter, Karl Dragutin Gorjanović-Kramberger also first considered the Neandertals members of the human species as he began to describe the Krapina remains and write on their importance, although he later called them Homo primigenius, after Schwalbe's (1901) use of Wilser's term. With the discovery of numerous fragmentary Neandertal specimens at Krapina (especially by 1905), Gorjanović did significant comparative work at the Natural History Museum in Vienna and
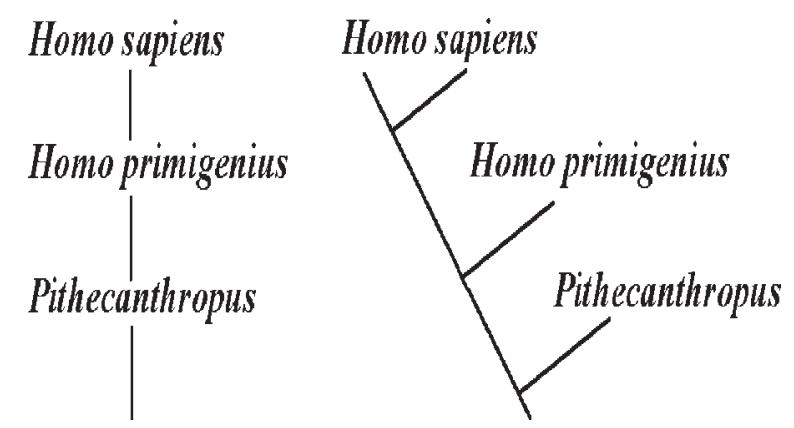

Fig. 1. Gustav Schwalbe's (1906) alternative arrangements of hominid phylogeny.

concluded that, contra Ranke, Neandertals vary more from modern races than the modern races differ from each other. Gorjanović explained this variation as a continuum: "Man has been developing from the ancient Diluvial populations toward recent man, and ... there are no sharp delineated borders between individual human characteristics ... Homo primigenius and Homo sapiens, as the extreme forms of a single genetic sequence, are opposites in terms of their osteological systems" (Radovčićci, 1988, p. 81, translated from Gorjanović-Kramberger, 1904).

This Central European understanding of Neandertals, developed before the turn of the century, came to describe Neandertals as a human group. However, varying more from human groups than human groups vary from each other is not the same as being equally related to all human groups, which a true out-group would have to be, and by the turn of the last century only Gustav Schwalbe $(1901,1906)$ understood this difference and depicted Neandertals as a human out-group (see Fig. 1). $\mathrm{He}$ considered both the possibility that this out-group was the ancestral condition, equally ancestral to all living races, and the alternative that it could be interpreted as a divergent sister species. The fact that he held these two to be equivalent demonstrates that he understood the meaning of out-group. He named Neandertals as a distinct species, not because of the amount of difference but because of Neandertals' out-group status. Schwalbe's insight was that whether evolutionary change or taxonomic divergence explained the central observation, Neandertals both differ more than human races differ from each other, and could be equally related to all races.

Thus it was in this taxonomic role first articulated by Schwalbe that Neandertals came to serve as an outgroup for examining the rest of human variation, in their ability to inform the understanding of human variation by playing the role of "other". This was and continues to be true in both the popular and scientific literatures; these are not as independent as one might imagine (Trinkaus and Shipman, 1993; Wolpoff and Caspari, 1997). Long after the natives of foreign lands, natives or "bushmen," could no longer serve as "other" and became inappropriate to judge our civilization and modernity by, there remained the Neandertal out-group to define modernity:

His large head, with the thick frontal bones, must have been very good for butting a brother Neanderthal, but it was no use against the stone wall of advancing civilization, and like the Tasmanian and 
Bushman, the Red Indian and Australian of nowadays, he fades out of the picture and his place is taken by a cleverer people. (Quennell and Quennell, 1945)

More than a half-century later, in a more serious context, Trinkaus (2006) argued that recent humans are far more derived than Neandertals; it is the human condition, and not the Neandertal condition, that might be the productive focus of evolutionary studies. Other researchers have approached questions of "modern human origins" from a similar perspective (Lieberman, 2008). In these and other studies Neandertals are upheld to serve as an out-group for humanity, and at some level out-groups are taxonomically distinct because properly constituted, an out-group should be equally related to all populations it is the out-group for.

The interpretation of fossil variation as taxonomic continued for some time in Central Europe, and spread to scientific communities both eastward and westward, quickly becoming (and remaining) the majority interpretation. Schoetensack (1908), for instance, named the Mauer mandible Homo heidelbergensis, Klaatsch and Hauser (1910) named the Combe Capelle specimen Homo aurignacensis, and so on. These names carried the same kinds of phylogenetic implications as Schwalbe's phylogeny, so that Schoetensack described an ancestral species in Homo heidelbergensis and Klaatsch's naming of fossil species (he named others as well) reflected his polygenic view that human races had multiple origins, sometimes in different primate species.

\section{NEANDERTALS INFORM HUMAN VARIATION IN THEIR ROLE AS ANCESTOR Anatomical ancestor}

Ironically, later in the century it was for the most part Central European paleoanthropologists, or paleoanthropologists of Central European descent, who reversed this intellectual development and led the effort to lower the level of taxonomic interpretation for Neandertals. With Hrdlička (1930), Weinert (1925), Stolyhwo (1908, 1937), and Weidenreich (1943a), by the middle of the last century emphasis had been placed on the interpretation of Neandertals as members of the human species. The Central European scholars, of course, were not alone in this endeavor (Pearson and Davin, 1924; Sergi, 1953).

But this retreat-stepping back from the taxonomic interpretation-required addressing two issues: did Neandertals fit within a human species, were Neandertals human ancestors, or at least (as Weidenreich, 1943a recognized) the ancestors of some humans? Many researchers now accept that Neandertals were within Homo sapiens, including some who answer the ancestry question more negatively (c.f. Bräuer, 2008 and others). While the question was no longer about species, for these and other paleoanthropologists, it was increasingly also not about a Neandertal race, but rather about whether Neandertals were in the human race. This is because the concept of human races (or subspecies, as were usually taken to mean the same thing) was falling into disrepute throughout the 20 th Century.

This change in thinking about a Neandertal race reflects many things. One of them was a switch from questioning how to explain variation to questioning how to explain ancestry (Wolpoff and Caspari, 1997). Another reflected the beginnings of a movement to drop the whole racial explanation of human variation. There is little doubt that much of this movement reflected a reaction to the events in Nazi Germany and the role of scientists, including anthropologists, in them. Boas, the German-born Jewish founder of the American Anthropological Association, became concerned about the fate of Jews in the Nazi state soon after Hitler was appointed chancellor. He organized the Lessing League to combat "the anti-Semitic agitation which is being carried on in this country," but realized that to be effective a scientific denouncement should not be made by a Jewish scientist.

The scientific community was not at all united on this issue. In the 1934 London meeting of the International Congress of Anthropological and Ethnological Sciences, attended by Boas, Haldane spoke out against racism, warning his audience against the abuse of science in support of race theories. He was not alone; an antiracist tract was published a year later by Huxley and Haddon (1935). It was the harbinger of the later American movement and questioned whether races actually existed, suggesting that "race" be replaced by "ethnic group." While Boas was unable to convince the Anthropological and Ethnological Sciences Congress to pass a resolution on the issue, the race issue was revisited after the war, and it soon became widely accepted, at least in anthropology, that in a biological sense there are no human races (Montagu, 1964).

Outside of anthropology race is most often used as a synonym for subspecies (Mayr, 1969, p. 44; Futuyma, 1986, p. 107-109; Templeton, 1998), and for most of its history this has been true within paleoanthropology (Boule, 1923; Dobzhansky, 1944; Weidenreich, 1946, 1947). Subspecies, however, are not a favored topic in modern biology; they don't exist in the indexes of many of recent textbooks, and when they do appear there are some times when subspecies refer to a taxonomically distinct variety of a species, but others when they are used to describe "a species in the making". It is little wonder that subspecies are for the most part no longer used to interpret past variation (Wolpoff et al., 1984), human or otherwise.

There has been considerable change in the terminology used to discuss Neandertals, and other taxonomic issues, that reflect changes in both anthropology and biology. Some of these changes reflect the consequences of the demise of subspecies categories. At one extreme, taxonomic explanations are provided (and often accepted) for virtually all past variation; these are almost invariably at the species level (Tattersall, 2000; Tattersall and Schwartz, 2008). On the other hand, race is no longer an organizing principle for human variation (Marks, 1995; Wolpoff and Caspari, 1997; Templeton, 1998; Caspari, 2003), and for all intents and purposes there is no accepted human taxonomy below the species level apart from the local population. The question of interest for paleoanthropology comes between these, if Neandertals are not considered a distinct species, with the demise of the race concept what are they then? Can Neandertals frame human variation as a human variety that is not an out-group? While few have recognized the role played by the temporal distance between Neandertals and the reticulating network of human races (Hawks and Wolpoff, 2003) in assessing their variation, this remains a key issue.

What can "anatomical ancestor" mean in this context? The one thing it cannot mean is that Neandertals are equally related to all living people, a "Neandertal Stage" (sensu Brace, 1967), because this would require Nean- 
dertals were the only ancestors of recent and living populations, as Schwalbe had portrayed them. When Weidenreich conceived of a "Neandertal Stage," he assumed that all recent archaic populations could be regarded as local Neandertals. But he had something different in mind because he was focused on processes of intraspecies variation. Weidenreich was quite clear about what local evolution means in this context-local ancestryand that implies European Neandertals cannot be an out-group because they were not equally related to everyone. So, logically, an ancestral Neandertal in Weidenreich's sense cannot serve as "other". Weidenreich made two related points about the Far Eastern evolutionary sequence that pertain equally well to Neandertals and demonstrates his understanding of this issue:

There can no longer be much doubt that certain modern Australian types ... resemble the Homo soloensis skulls of Java in all essential features so closely that they can be interpreted only as a further evolutionary stage of the latter.... [However] to make probable that European Neanderthalian did not develop into the Australian of today does not at all prove he did not evolve into any other racial group of Homo sapiens. (Weidenreich, 1943a, p. 44)

\section{And}

At least one line leads from Pithecanthropus and Homo soloensis to the Australian aborigines of today. This does not mean, of course, that I believe all the Australians of today can be traced back to Pithecanthropus, or that they are the sole descendents of the Pithecanthropus-Homo soloensis line. (Weidenreich, 1943b, p. 249-250)

So Weidenreich's perspective for Europeans would be that as far as their anatomical ancestry can be reconstructed, Neandertals are among the ancestors of Europeans; but this neither means they were the unique ancestors of Europeans, nor that Europeans were their sole descendents. In this interpretation, anatomical ancestor does not mean out-group. He wrote this a year before Dobzhansky (1944) made many of the same points.

\section{Hypotheses about anatomical ancestry can be tested}

Was Weidenreich's perspective valid for European ancestry-is there anatomical evidence that Neandertals are among the ancestors of Europeans? Or can this interpretation be refuted by the demonstration that Neandertals were a unique lineage and a distinct species?

This question can be addressed by several kinds of evidence. The longest recognized evidence is that postNeandertal anatomical variation in Europe includes specifically Neandertal features. These observations have been in the literature for some time, and continue to accumulate (Wolpoff and Caspari, 1996; Frayer, 1992, 1997; most recently Duarte et al., 1999; Wolpoff et al., 2001; Zilhão and Trinkaus, 2002; Trinkaus et al., 2003; Frayer et al.,. 2006; Soficaru et al., 2006; Zilhão, 2006; Rougier et al., 2007; Trinkaus, 2007). This evidence, however, has a significant acquisition bias, because of how observations are chosen to address the question of Neandertal ancestry. Anatomical variation specific to Neandertals, or very common in the sample, is only useful for hypoth-
TABLE 1. Characteristics used in the pairwise difference analyses summarized in Figures 1 and 2

Whole cranium

"Teardrop" shape (seen from top)

Cranial rear rounded (seen from back)

Occipital bun

Asterionic parietal thickness ( $>9 \mathrm{~mm}$ )

Lambdoidal occipital thickness $(>8 \mathrm{~mm})^{\mathrm{a}}$

Occipital

Vertical occipital face short

Sagittal groove along vault posterior

Occipital plane long (>60 mm)

Suprainiac fossa, elliptical form

Paramastoid crest prominent

Occipitomastoid crest prominent ${ }^{\mathrm{a}}$

Broad occiput (>120 mm)

Retromastoid process prominent

Nuchal torus extends across occiput

Temporal

Mastoid-supramastoid crests well separated

Mastoid process projects minimally ${ }^{\mathrm{a}}$

Glenoid articular surface flattened

Supraglenoid gutter long ${ }^{\mathrm{a}}$

External auditory meatus leans forward ${ }^{\mathrm{a}}$

Mastoid tubercle $^{\mathrm{a}}$

Frontal

Glabellar depression

Frontonasal suture arched

Supraorbital center dips downward

Broad frontal (>125 mm)

Central frontal boss

Frontal long (gl-br > 113)

Frontal keel

Anterior temporal fossa border angled ${ }^{a}$

Lateral supraorbital central thinning ${ }^{a}$

Medial height of supraorbital large $(>19 \mathrm{~mm})$

Characteristics were developed from the comparisons in the text, with the criteria of representing structures on all parts of the cranium and maximizing the size of the comparative sample. We chose the observations which we felt could be unambiguously and repetitively scored with accuracy.

${ }^{a}$ Not preserved and therefore not used in Mladeč 6 analysis.

esis testing when it is reasonable to discount homoplasy. The probability that homology is the best explanation of similarity is reduced when samples are closely related, and it is best to consider additional information that helps minimize mistaking homoplasy for homology. One approach is to omit cases when similarity could be accounted for by the explanation that the similarity appeared because of a similar adaptive response. For instance, features reflecting cold adaptation may be found in other cold adapted populations, contemporaneous or putative descendents, but these would not necessarily reflect any specific genetic relationship. At the minimum, considering this problem and acting conservatively means that features with obvious adaptive value should not be considered when issues of ancestry are addressed.

Evidence of a dual ancestry of modern Europeans that includes Neandertal and nonNeandertal ancestors needs to involve comparisons of Neandertals and postNeandertal Europeans for the appearance of features that are unique to the two samples or of exceptionally high frequency in them. One such hypothesis involves the Aurignacian males from the Mladeč Cave in Moravia (Wolpoff et al., 2001; Frayer et al., 2006). For the purpose of hypothesis testing, dual ancestry is specified to mean equal ancestry for the early modern sample in earlier Euro- 


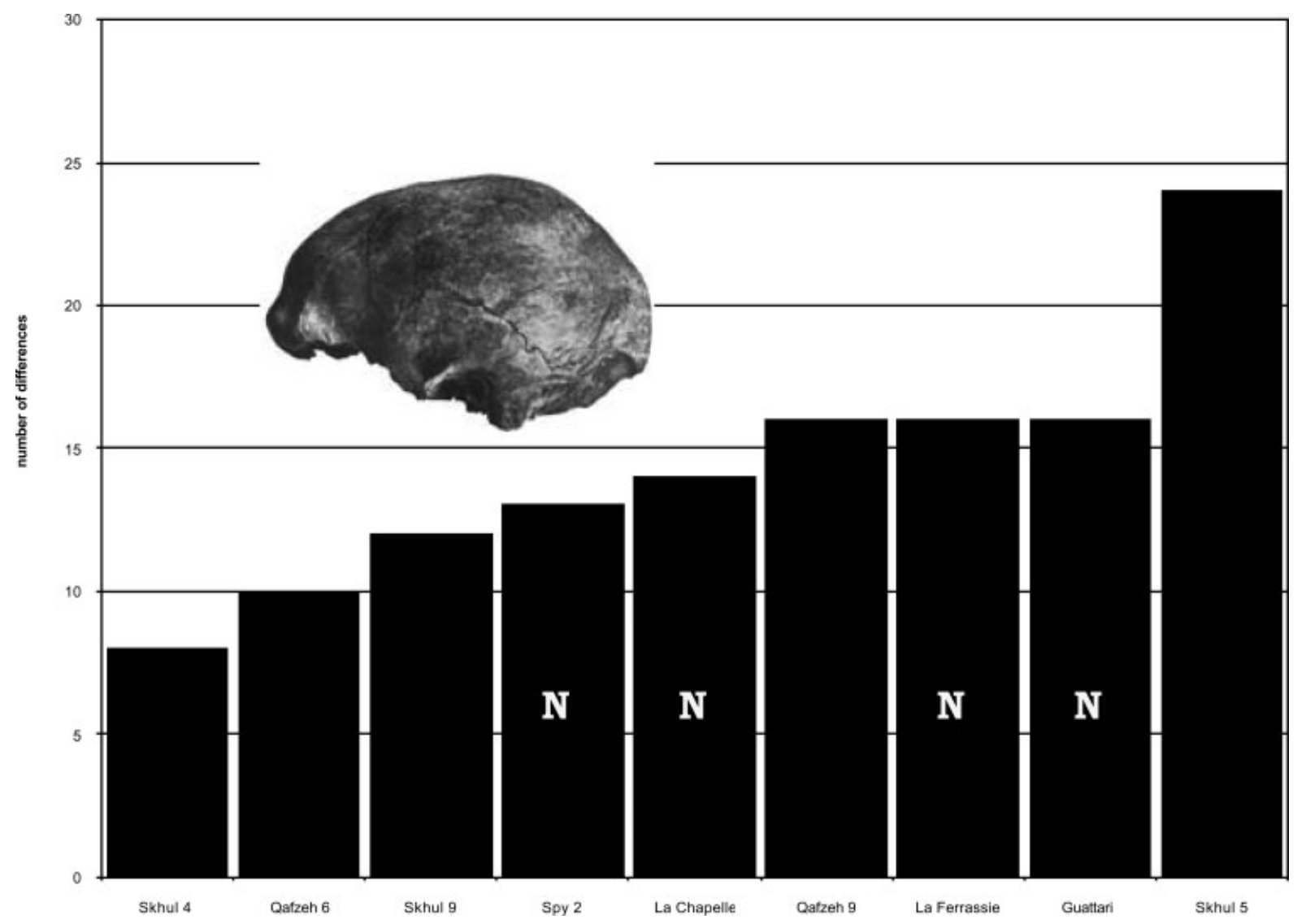

Fig. 2. Pairwise differences between Mladeč 5 and the most complete Neandertal ("N" bars) and Skhul/Qafzeh males. 30 nonmetric traits (Table 1) are used in this analysis (modified from Frayer et al., 2006). The specimens are arranged in order of how many differences the comparisons with Mladeč 5 show.

pean Neandertals and in archaic humans from Skhul and Qafzeh caves, to provide clear predictions for testing.

The equal ancestry hypothesis was examined using nonmetric observations for putative ancestors of the Mladeč crania (Table 1), the most complete adult male crania from each sample because both Mladeč crania are adult males (four Neandertals, five Skhul/Qafzeh, see the Figs. 2 and $3 x$-axes for details). Thirty nonmetric traits from all parts of the cranium were scored as present or absent, so that the differences could be validly combined without weighing one variable more than another. Three of the nonmetric variables completely separated the Neandertal and Skhul/Qafzeh samples. Of them, the Mladeč crania were like the Neandertals in two, and like Skhul/Qafzeh in one. Seven additional traits almost completely separated the putative ancestral samples. Of these, the Mladeč crania were like the Neandertals in four and like Skhul/Qafzeh in two. For the seventh trait, one Mladeč cranium was like each. In spite of the predominance of Neandertal resemblances for this subset of 10 traits, the normal approximation of the binomial distribution shows the equal ancestry hypothesis cannot be rejected at the 0.05 level.

Because this analysis was based on characteristics of the groups themselves, for a second analysis the relationship of individuals was addressed in a way that ignored group assignments. The pairwise differences between each of the two Mladeč crania and the eight other specimens were calculated from the 30 nonmetric traits. These are shown in Figures 1 and 2. The pairwise comparisons consider individuals who cluster more closely to be more closely related to each other. They do not necessarily assume a full independence of the traits, just as independence cannot be assumed for nucleotide differences in the nonrecombining mtDNA molecule when pairwise comparisons are used in genetic analysis (Krings et al., 1997). The required assumption is that traits more closely linked are randomly distributed throughout the data set. The procedure is conservative, in that the absence of data for a specimen is considered the absence of difference. Missing data in the comparative samples are not randomly distributed. The Skhul/ Qafzeh crania have more missing data than the Neandertals do. This means that in this specific analysis, the results are biased to show more similarities with the Skhul/Qafzeh remains.

Pairwise analysis was used by Frayer et al. (2006) to examine the relationship of the Mladec crania to the individuals in the two putative ancestors. The number of differences between each Mladeč cranium and the others were tallied, and the figures aligned the specimens in order of increasing difference. The average pairwise difference between Mladeč 5 and the Neandertal sample is 14.8 , and between it and the Skhul/Qafzeh sample is 14.0 , virtually the same. For Mladec 6 the corresponding comparisons are 7.8 and 11.6 differences, so it is closer to the Neandertal sample. A Sample Runs test (Swed 


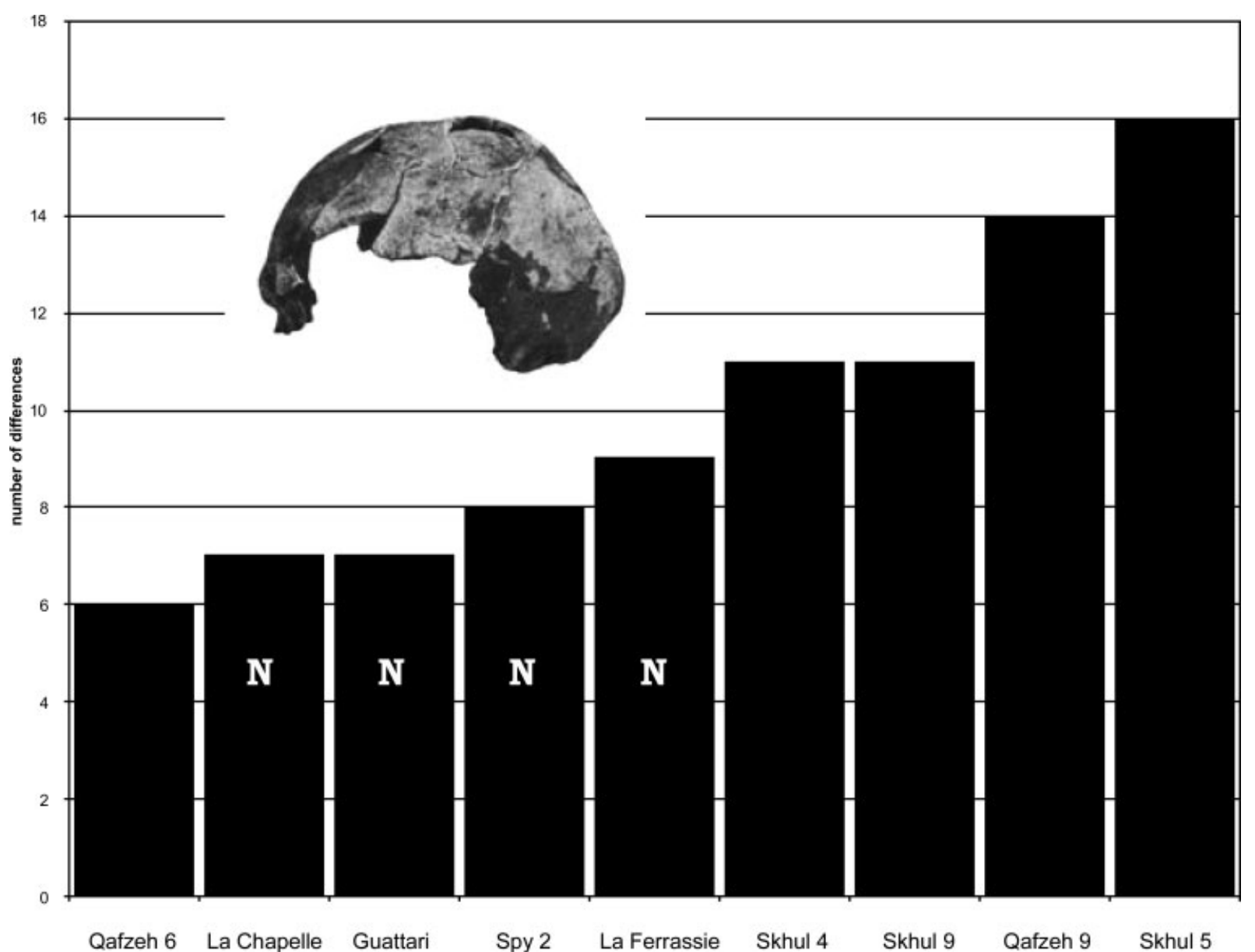

Fig. 3. Pairwise differences between Mladeč 6 and the most complete Neandertal ("N" bars) and Skhul/Qafzeh males. 22 nonmetric traits are used in this analysis (Table 1), less than the number for Mladeč 5 because the vault is less complete (modified from Frayer et al., 2006). The specimens are arranged in order of how many differences the comparisons with Mladeč 6 show.

and Eisenhart, 1943) was used to examine whether the ordering of Neandertal and Skhul/Qafzeh crania, based on the number of pairwise differences from the Mladeč crania, is random (the null hypothesis). Randomness can be rejected at the $P=0.05$ level when there are 2 or less, or 9 or more runs from the same site, for a sample of this size. There are 5 runs for Mladeč 5 and 3 runs for Mladeč 6-randomness in the order of pairwise similarities cannot be rejected. These data fail to reject an equal ancestry hypothesis, and thereby disprove the notion that the Mladeč crania are uniquely related to either Neandertals or to Skhul/Qafzeh.

These research results indicate that Neandertal populations had a significant input in the ancestry of early postNeandertal Europeans from Mladeč, also a conclusion of research on other postNeandertal Europeans (Crummett, 1994; Duarte et al., 1999; Churchill and Smith, 2000; Zilhão and Trinkaus, 2002; Trinkaus et al., 2003; Wolpoff et al., 2004; Soficaru et al., 2006, 2007; Trinkaus, 2006; Zilhão, 2006; Rougier et al., 2007; Frayer and Wolpoff, 2008). It follows that early postNeandertal Europeans have a dual ancestry, in both Neandertals and another group or groups. The dual ancestry hypothesis explicitly tested for the Mladeč males is also used to explain variation in the Předmostí and other early postNeandertal European remains (Frayer and Wolpoff, 2008). Dual ancestry, a consequence of population mixing, is a key element in Multiregional evolution (Wolpoff et al., 2000).

\section{Genetic ancestry}

The Mladeč discussion addressing the place of Neandertals in human evolution, detailed above, actually began over 80 years ago, with the publication of Szombathy's monograph (1925), and concern about the place of Neandertals has been ongoing. Genetics provide the first really new source of data to address the issue. Genetic information is now available for variation in both the mitochondrial and the nuclear genome, for Neandertals and for modern humans.

Mitochondrial DNA has turned out to be of limited use for this specific issue (Clark, 2008) because the Neandertal haplogroup no longer exists, and because selection often and easily affects mtDNA evolution (Bazin et al., 2006; Eyre-Walker, 2006), independently of population history. MtDNA related to Neandertals is known from hominids across Eurasia; it is sometimes assumed that this means Neandertals as a population were spread across Eurasia (Krause et al., 2007b), although this 
interpretation requires that Neandertals were a separate lineage with unique mtDNA and there is no independent basis for this assumption. What we do know is that the Neandertal mitochondrial haplogroup is the only one identified in hominids older than $40 \mathrm{kyr}$ or so, and disappeared in a recent selective sweep. If this reflects widespread population replacement, we are yet to see its genetic consequences in nuclear DNA, and so it seems that this sweep most probably involved selection on the mitochondrial gene alone (Hawks, 2006).

The best direct evidence for a recent selective sweep comes from the publication of the full mitochondrial genome of the Vindija 33.16 Neandertal (Green et al., 2008). One gene (COX2) was found that had four repeated amino acid substitutions in the human (i.e. surviving) mtDNA lineage. Hawks, on his BLOG, points out that each of these human-specific mutations is also found in some other primate species and therefore the changes were probably established by recurrent selection. Results such as these are expected if the surviving mtDNA lineage replaced the Neandertal lineage because of selection.

Nuclear DNA is of much more interest, and of course involves many genes, not just one. We may anticipate two related problems in interpreting nuclear DNA. First, we may expect that most uniquely human alleles are shared among all populations, including Neandertals, because of their close relationship. Populations, if not species, for the most part differ in the frequencies of shared alleles. Searching for allele differences alone would underestimate any genetic comparison with Neandertals. On the other hand, the second expectation is of an acquisition bias, in that identifying "human" genes in the Neandertal gene pool will always be problematic because of the potential for contamination of the fossils with modern human sequences. Moreover, we can only easily identify Neandertal genes entering the "human" gene pool when they are under selection, by taking advantage of the consequences of introgression (see below).

Modern alleles in Neandertal samples. Knowledge of nuclear genetic variation in Neandertals can directly address the issue of gene exchanges. At this time such knowledge is based on the analysis of only a few specimens. Perhaps the most important case is the FOXP2 gene (Krause et al., 2007a) in two El Sidrón (Spain) specimens, whose discovery was surprising to workers who assumed minimal Neandertal language ability. When these specimens were excavated, to avoid contamination they were frozen and immediately shipped to Leipzig, where they were analyzed in clean room conditions. FOXP2 is one of the many genes related to human language (Enard et al., 2002). It is not a "language gene" in that its effects are not critical for human language, although FOXP2 was selected for because of its role in language.

If the human hyoid bone form is important in language production, this anatomy was present much earlier, in the SH sample at Atapuerca ( Martínez et al., 2008), and the Atapuerca hominids had auditory capacities in the high human frequency range used in language (Martinez et al., 2004). So the question is whether FOXP2 is present because of common descent from an ancestor with the gene. Arguing against this is evidence that the human form of FOXP2 has a recent origin (Enard et al., 2002), $200 \mathrm{kyr}$ ago or less. This is less than the range divergence times estimated for Neandertals, by those who believe there was a lineage divergence. The pattern of disequilibrium also supports a recent origin, and Coop et al. (2008) argue that the last selective sweep affecting human FOXP2 was $\sim 42 \mathrm{kyr}$.

Could FOXP2 be in the Neandertal sample because of contamination? Careful treatment of these recently discovered specimens argues against this, but does not disprove it, and contamination problems are significant in human bones and fossils, if anything multiplying in effect past the time of contamination (Sampietro et al., 2006). Krause et al. tested for the possibility by identifying seven alleles in the Vindija 33.16 Neandertal genome that do not appear in humans today, and looking at the relevant sites in the El Sidrón bones. Only the Neandertal form was found, further supporting the argument against contamination.

Yet, it is possible that these data reflect contamination. Briggs et al. (2007) identify more potential sources of contamination than generally considered, with some alterations resulting from the rapid sequencing technology itself. One major recommendation of this paper is the isolation of the fossil from the time of discovery, and its preparation and data extraction under laboratory conditions. These conditions seem to have been met during the recovery of in two El Sidrón Neandertal specimens.

If FOXP2 is not shared because of descent from a common ancestor with the gene, and if the ever-present contamination possibility is not the cause, the presence of FOXP2 has a good chance of being the result of interbreeding between Neandertals and other populations. The direction (from Neandertals or to Neandertals) is uncertain.

Archaic alleles in modern populations. What about archaic alleles appearing in modern populations? Examining the other side of genetic exchanges, studies of nuclear genetic variation in current populations that seek evidence of archaic input, avoids the contamination problem. Plagnol and Wall (2006) conservatively estimate a nonnegligible 5\% nuclear gene ancestry from archaic humans in the genes they sampled. Genetic studies follow earlier research where the inheritance of human genetic variation from Neandertals and other archaic groups was inferred from the distribution of gene products such as proteins in living populations (Morral et al., 1993; Deeb et al., 1994; Harding et al., 2000).

However, there is now direct evidence of alleles in the gene pool today that appear to be Neandertal-derived (Zietkiewicz et al., 2003; Garrigan and Kingan, 2007), and many of these have been under recent selection. Still in their early stages, these studies indicate that Neandertal alleles, and the alleles of other archaic populations, regularly entered the modern gene pool (Eswaran et al., 2005) and came to be under positive selection there (Hawks et al., 2007a). Hawks and Cochran (2006, p. 104) note that with selection, only a very small number of interbreeding events may have been involved:

If the modern human population expanded at a rate of $1 \%$ per generation, then an introgressive allele with $s 0.01$ (i.e., a $1 \%$ fitness advantage) would have a $95 \%$ probability of fixation in modern humans, with only 74 archaic-modern matings. For an allele with a $5 \%$ fitness advantage, the corresponding number of events would be only 24 . 
With selection there is no longer an "issue" of whether there was enough gene flow from Neandertals to have a significant effect (an "issue" whose discussion has taken up an exceptional amount of time and effort), because these are a very small number of encounters with consequences that are not influenced by their number but by the magnitude of selection and by subsequent human population expansion. They are minimal estimates of what would be required to account for the observed introgressions (see below) of genes under selection, and more regular interchanges between the populations would have the same effects. The demonstration of cultural contacts and regular exchanges is in several recent analyses of archaeological remains (Zilhão, 2001; D’Errico et al., 2003; D’Errico, 2003; Zilhão et al., 2006).

There are a number of cases of archaic genes entering populations ancestral to living populations. For the most part these cases can be most easily recognized when they were introgressions; that is, when key alleles entered the human population, out of archaic human varieties including Neandertals, substantially later than when they evolved. Such alleles increased in frequency over time under selection (Hawks et al., 2007a). This distinguishes them from the fate of some of the anatomical features that Neandertals can be shown to have contributed to the human gene pool (Frayer, 1997). Part of the difference between the fate of Neandertal anatomical traits and genetic traits is a consequence of the different acquisition errors, reflecting bias in how genetic and anatomical data are selected. But the origin of these alleles is far older than the time when they first entered the human gene pool.

FOXP2 may be an example of such a gene, if the direction of its dispersal was out of Neandertals rather than into them, since the gene evolved earlier than it dispersed. Another example is the microcephalin D haplogroup, one of the many regulating human development (Evans et al., $2005,2006)$. While the nonD haplogroups have a coalescence time of close to 2 myr, the D haplogroup diverged from the ancestral condition at about 37 kyr (Hawks et al., 2007b). Nevertheless, the D haplogroup has a $70 \%$ worldwide frequency. These facts strongly implicate selection. Evans et al. $(2005,2006)$ suggest that there has been an adaptive introgression into the human population for this microcephalin haplogroup. In this particular case the Neandertals are the most likely source population because today the $\mathrm{D}$ haplogroup is rare in Africa, but common in the New World, New Guinea, and especially in Europe. If the D haplogroup increased under selection a long-time ago in Africa, it would be most common there, instead. However, nonD haplogroups are the common ones in Africa (and elsewhere), but there is almost no evidence of recombination with the $\mathrm{D}$ haplogroup. This means that the $\mathrm{D}$ haplogroup attained high frequency because of recent selection after introduction into populations directly ancestral to living Europeans (and certain others).

There is a very similar case at the MAPT locus (Hardy et al., 2005), that has been linked to a possible role in Alzheimer's and Parkinson's disease. There are two haplogroups today that diverged about 3 myr ago. The European form is very rare in Africans and seems to have been very recently selected for because of its young coalescence (Stefansson et al., 2005).

Finally, not all introgressions are European, a fact that provides direct genetic evidence of ancient population structure beyond Europe (although see Garrigan et al., 2005a; Templeton, 2005). RRM2P4 is a pseudogene on the $\mathrm{X}$ chromosome that appears functionless. There are two haplogroups that diverged at about 2.4 myr (Garrigan et al., 2005b). One of these is very common in central and eastern Asia but rare in African samples, a distribution which, given its divergence time is compatible with introgression (Hawks et al., 2007b).

This evidence of past introgressions provides some additional insight into past population structure, because introgression is very rare (if at all) in recent genetic evolution. This is because of the recent and current size of the human species, and the fact that no populations are truly isolated. Alleles that were of significant adaptive value in some populations, but did not find their way into other human populations until long after they appeared, could reflect the fact that these populations were far smaller and more isolated from each other than populations are today. Such a past population structure is compatible with the million year or longer period that has been required to establish reproductive isolation in larger mammalian species (Curnoe et al., 2006; Holliday, 2006). What has recently changed in the human species is the very large population increases of the past $50 \mathrm{kyr}$, and the effects of virtually universal exogamy rules in human societies, far more often in contact as the human population increases.

\section{NEANDERTALS INFORM HUMAN VARIATION IN THEIR ROLE AS A HUMAN RACE}

Do these observations, and their interpretations, mean we can accept Neandertals as a human race, as others have before? In the earlier literature race was used synonymously with subspecies, and this is still largely the case in the biological literature.

A taxonomic division [of variation] equates race with the concept of a subspecies, a division of a species into distinct and distinguishable types. A good example would be the three different subspecies of gorilla.... the three groups are physically and geographically distinct (Relethford, 2008, p. 379).

A taxonomic division also implied common descent.

The dismissal of human races as an organizing structure for human biology was for many reasons, including political reasons, but there is a firm biological basis for it in the distribution of genetic variation (Templeton, 1998), that to some extent is reflected in the distribution of anatomical variation.

- Extant human anatomical variation does not attain the subspecies level; populations are neither different enough, nor separated enough, for a subspecies interpretation of their variation to be valid.

- The ratio of within group to between group variance is very high in humans.

- There is no treeness for human groups (Templeton, 1998).

Thus, the idea that there were once pure human races is dead and buried, and if race cannot reflect common descent, and if there is no validity to the precept that human races are constellations of biological characters that show greater differences between each other than variation within one of them, race can only have a social definition (Marks, 1995; Caspari, 2003; many others). There simply are no clearly distinct types of humanity (Graves, 2001), and there is no racial taxonomy for the living. 
Has this always been the case? If there are no races today-accepting that human geographic variation is not taxonomic-does this mean that there were no races in the human past? Or, is it possible that Neandertals fit the description of a subspecies as we understand it today? The modern understanding of subspecies comes from the New Synthesis, especially from the works of Mayr (1942) and Dobzhansky (1944). For them, subspecies combined groups of local populations by anatomical similarity and geographic distinctness, in a taxonomic grouping (by descent). Although criticized by Wilson and Brown (1953), subspecies continue to describe intraspecies variation when it is distinctly geographic; but admittedly, for the most part modern usage is not common because intraspecies variation is not often studied. However, this happens to be a significant problem in human studies where, as discussed above, this variation is almost never regarded as taxonomic.

Dobzhansky (1944) directly addressed the question of whether past hominid samples such as Neandertals might be subspecies. For him the compelling support for a Neandertal subspecies came from the newly published Mount Carmel remains (Skhul and Tabun), which he interpreted as the result of mixture between two subspecies that were obviously not reproductively isolated, and not a single population "in the throes of evolutionary change", as McCown and Keith (1939) interpreted the sample. Dobzhansky (1944, p. 259) noted that

The Mount Carmel population also shows that ... a morphological gap as great as that between the Neanderthal and the modern types may occur between races, rather than between species.

For Dobzhansky, a past polytypic human species was not an exceptional situation, since at the time he also regarded living humans as polytypic (c.f. Mayr, 1942), with recognizable geographic races (albeit races that, unlike Neandertals, are "imperfectly differentiated"), as we no longer do.

Most researchers now agree that Neandertals are in the same species as living people and as populations penecontemporary with Neandertals that are regarded as modern humans or their immediate ancestors, such as Omo, Herto, or Qafzeh. Besides the evidence of mixture, reasons for this include direct evidence of gene exchanges as detailed above, the seemingly parallel evolution of putative Neandertal and modern lineages (Wolpoff and Caspari, 1996; Wolpoff and Lee, 2007), anatomical evidence for dual ancestry for early "moderns" also discussed above (Wolpoff et al., 2001; Trinkaus et al., 2003; Frayer et al., 2006), the statistical demonstration ["statistical" is emphasized here because most discussions of this issue are based on assertions about differences based on the recognition of autapomorphies that lack any sense of population variation (Lieberman, 2008; Pearson, 2008)] that Neandertals do not differ from "moderns" more than living geographic groups differ from each other (Ahern, 2006), and other issues in including archaeological interchangeability in both Europe and western Asia (D'Errico, 2003; D'Errico et al., 2003; Zilhão, 2006).

In terms of magnitude of variation, significant isolation, and regional identity, Neandertals fit the description of subspecies in ways that no living or recent human groups do. In particular, they fit the description of subspecies as allotaxa ("morphologically diagnosable yet not reproductively isolated" populations) that Jolly
(2001) discusses, in an essay that proposes "Neandertals and AfroArabian 'premodern' populations may have been analogous to extant baboon (and macaque) allotaxa" (p. 177).

The most significant new evidence for regarding Neandertals as a subspecies of Homo sapiens is that Neandertal genes dispersed under selection to populations with descendents, where they led to significant adaptive changes (Evans et al., 2005, 2006; Hawks et al., 2007a). We don't have the corresponding information for all of the Neandertal nuclear genome, the million base pair sample known at this time is far too small (Green et al., 2006), and the potential problems of contamination are as yet too great, but even now it is seems possible that some Neandertals had key nuclear genes such as FOXP2 (Krause et al., 2007a) that entered their population under selection, if not actually evolving in Neandertals and dispersing outwards. The introgression of Neandertal genes into the human genome indicates that the gene flow was two way.

At the same time, the recent introgressions of genes that evolved at a much earlier time suggest that Neandertal populations were significantly isolated from other human populations, as they may well have been from each other [we have little evidence addressing this (Excoffier, 2006)]. The new evidence of restricted gene flow, combined with older observations of a distinct geographic range and the magnitude of anatomical differences between Neandertals and their penecontemporaries, suggest that unlike any population today, it is reasonable to interpret Neandertals as a human subspecies. Neandertals, it would appear, are the best established demonstration that humans in the past, like many other mammals (Mayr, 1963), formed distinct races.

\section{ACKNOWLEDGMENTS}

I thank Keith Hunley and Heather Joy Hecht Edgar for the invitation to present my work at the Reconciling Race Symposium at the University of New Mexico, support to attend the conference, and the invitation to contribute to this volume. The discussions at the conference were invaluable in preparing this paper, and more broadly for the author's continued reëvaluating of the anthropological roles played by race. That understanding, and the author's understanding of the history of the profession, is largely informed by Dr. Rachel Caspari, and I gratefully acknowledge this debt. I thank the AJPA editor and two anonymous reviewers, and Rachel Caspari, John Hawks, Tom Roček, and Karen Rosenberg for their very helpful editing suggestions. I relied on John Hawks web blog (http://johnhawks.net/weblog) for commentary and analysis of the genetic information, and would recommend this site to all.

\section{LITERATURE CITED}

Ahern JCM. 2006. Non-metric variation in recent humans as a model for understanding Neanderthal-early modern differences: just how "unique" are Neanderthal unique traits? In: Havarti K, Harrison T, editors. Neanderthals revisited: new approaches and perspectives. Dordrecht: Springer. p 255-268.

Bazin E, Glémin S, Galtier N. 2006. Population size does not influence mitochondrial genetic diversity in animals. Science 312:570-572.

Boule M. 1923. Les Hommes Fossiles. Eléments de Paléontologie Humaine. Paris: Masson. 
Brace CL. 1967 The stages of human evolution. Englewood Cliffs: Prentice-Hall.

Bräuer G. 2008. The origin of modern anatomy: by speciation or intraspecific evolution? Evol Anthropol 17:22-37.

Briggs AW, Stenzel U, Johnson PLF, Green RE, Kelso J, Prüfer K, Meyer M, Krause J, Ronan MT, Lachmann M, Pääbo S. 2007. Patterns of damage in genomic DNA sequences from a Neandertal. Proc Nat Acad Sci USA 104:14616-14621.

Caspari R. 2003. From types to populations: a century of race, physical anthropology and the American Anthropological Association. Am Anthropol 105:63-74.

Churchill SE, Smith FH. 2000. Makers of the early Aurignacian of Europe. Yrbk Phys Anthropol 43:61-115.

Clark AG. 2008. Genome sequences from extinct relatives. Cell 134:388-389

Coop G, Bullaughey K, Luca F, Przeworski M. 2008. The timing of selection at the human FOXP2 gene. Mol Biol Evol 25:1257-1259.

Crummett TL. 1994. The evolution of shovel shaping: regional and temporal variation in human incisor morphology, Ph.D. dissertation, University of Michigan. Ann Arbor: University Microfilms.

Curnoe DA, Thorne AG, Coate JA. 2006. Timing and tempo of primate speciation. J Evol Biol 19:59-65.

Deeb SS, Jørgensen AL, Battisi L, Iwasaki L, Motulsky AG. 1994. Sequence divergence of the red and green visual pigments in the great apes and man. Proc Natl Acad Sci USA 91:7262-7266.

D'Errico F. 2003. The invisible frontier: a multiple species model for the origin of behavioral modernity. Evol Anthropol 12:188-202.

D'Errico F, Julien M, Liolios D, Van Haren M, Baffier D. 2003. Many awls in our argument. Bone tool manufacture and use in the Châtelperronian and Aurignacian levels of the Grotte de Renne at Arcy-sur-Cure. In: Zilhão J, D'Errico F, editors. The chronology of the Aurignacian and of the transitional technocomplexes. Dating, stratigraphies, cultural implications. Trabalhos de Arqueologica 33:247-270.

Dobzhansky TH 1944. On species and races of living and fossil man. Am J Phys Anthropol 2:251-265.

Duarte C, Maurício J, Pettitt PB, Souto P, Trinkaus E, van der Plicht H, Zilhão J. 1999. The Early Upper Paleolithic human skeleton from the Abrigo do Lagar Velho (Portugal) and modern human emergence in Iberia. Proc Natl Acad Sci USA 96:7604-7609.

Enard W, Przeworski M, Fisher SE, Lai CSL, Wiebe V, Kitano T, Monaco AP, Pääbo S. 2002. Molecular evolution of FOXP2, a gene involved in speech and language. Nature 418:869-872.

Eswaran V, Harpending H, Rogers AR. 2005. Genomics refutes an exclusively African origin of humans. J Hum Evol 49:1-18.

Evans PD, Gilbert SL, Mekel-Bobrov N, Vallender EJ, Anderson JR, Vaez-Azizi LM, Tishkoff SA, Hudson RR, Lahn BT. 2005. Microcephalin, a gene regulating brain size, continues to evolve adaptively in humans. Science 309:1717-1720.

Evans PD, Mekel-Bobrov N, Vallender EJ, Hudson RR, Lahn BT. 2006. Evidence that the adaptive allele of the brain size gene microcephalin introgressed into Homo sapiens from an archaic Homo lineage. Proc Natl Acad Sci USA 103:1817818183.

Excoffier L. 2006. Neandertal genetic diversity: a fresh look from old samples. Cur Biol 16:R650-R652.

Eyre-Walker A. 2006. Size does not matter for mitochondrial DNA. Science 312:537-538.

Fraipoint J, Lohest M. 1887. La race humaine de Néanderthal ou de Canstadt en Belgique: recherches ethnographiques sur des ossements humaines, découverts dans dépots, quaternaires d'une grotte à Spy et détermination de leur âge géologique. Arch Biol (Liege) 7:587-757.

Frayer DW. 1992. Evolution at the European edge: Neanderthal and the Upper Paleolithic relationships. Prehist Europeenne 2:9-69.

Frayer DW. 1997. Perspectives on Neanderthals as ancestors. In: Clark GA, Willermet CM, editors. Conceptual issues in modern human origins research. New York: Aldine de Gruyter. p 220-235.
Frayer DW, Jelínek J, Oliva M, Wolpoff MH. 2006. Aurignacian male crania, jaws, and teeth from the Mladeč Caves, Moravia, Czech Republic. In: Teschler-Nicola M, editor. Early modern humans at the Moravian Gate: The Mladeč caves and their remains. Wien: Springer. p 185-272.

Frayer DW, Wolpoff MH. 2008. The importance of the Prrrcaron; edmostí human remains. In: Velemínská J, Brůžek J, editors. Early modern humans from Přmostí near Přerov, Czech Republic. Prague: Academia. Chapter 4, p 35-30.

Futuyma DJ. 1986. Evolutionary biology. Sunderland: Sinauer.

Garrigan D, Hammer MF. 2006. Reconstructing human origins in the genomic era. Nat Rev Genet 7:669-680.

Garrigan D, Kingan SB. 2007. Archaic human admixture, a view from the genome. Cur Anthropol 48:895-902.

Garrigan D, Mobasher Z, Kingan SB, Wilder JA, Hammer MF. 2005a. Deep haplotype divergence and long-range linkage disequilibrium at Xp21.1 provides evidence that humans descend from a structured ancestral population. Genetics 170:1849-1856.

Garrigan D, Mobasher Z, Severson T, Wilder JA, Hammer MF. 2005b. Evidence for archaic Asian ancestry on the human X chromosome. Mol Biol Evol 22:189-192.

Gorjanović-Kramberger D. 1904. Potijč e li moderni čovjek ravnó od dilúvijalonga Homo primigeniusa? Beograd: I Kongress srpskih lekara i Prirodnjaka. p 1-8.

Graves LL. 2001. The emperor's new clothes: biological theories of race at the millennium. New Brunswick: Rutgers University Press.

Green RE, Krause J, Ptak SE, Briggs AW, Ronan MT, Simons JF, Du L, Egholm M, Rothberg JM, Paunovic M, Pääbo S. 2006. Analysis of one million base pairs of Neanderthal DNA. Nature 444:330-336.

Green RE, Malaspinas A-S, Krause J, Briggs AW, Johnson PLF, Uhler C, Meyer M, Good JM, Maricic T, Stenzel U, Prüfer K, Siebauer M, Burbana HA, Ronan M, Rothberg JM, Egholm M, Rudan P, Brajković D, Kućan Ž, Gušić I, Wilkström M, Laakkonen L, Kelso J Slatkin M. 2008. A complete Neandertal mitochondrial genome sequence determined by highthroughput sequencing. Cell 134:416-426.

Harding RM, Healy E, Ray AJ, Ellis NS, Flanagan N, Todd C, Dixon C, Sajantila A, Jackson IJ, Birch-Machin MA, Rees JL. 2000. Evidence for variable selective pressures at MC1R. Am J Hum Genet 66:1351-1361.

Hardy J, Pittman A, Myers A, Gwinn-Hardy K, Fung HC, de Silva R, Hutton M, Duckworth J. 2005. Evidence suggesting that Homo neanderthalensis contributed the H2 MAPT haplotype to Homo sapiens. Biochem Soc Trans 33:582-585.

Hawks, J. 2006. Selection on mitochondrial DNA and the Neanderthal problem. In: Harvati K, Harrison T, editors. Neanderthals revisited: new approaches and perspectives. Dordrecht: Springer. p 221-238.

Hawks J, Cochran G. 2006. Dynamics of adaptive introgression from archaic to modern humans. PaleoAnthropol 2006:101-115.

Hawks J, Cochran GM, Harpending HC, Lahn BT. 2007a. A genetic legacy from archaic Homo. Trends Genet 24:19-23.

Hawks J, Wang ET, Cochran GM, Harpending HC, Moyzis RK. 2007b. Recent acceleration of human adaptive evolution. Proc Natl Acad Sci USA 104:20753-20758.

Hawks J, Wolpoff MH. 2003. Sixty years of modern human origins in the American Anthropological Association. Am Anthropol 105:87-98.

Henke W. 2008. Gorjanović Kramberger's research on Krapina its impact on paleoanthropology in Germany. In: Monge J, Mann A, Frayer DW, Radovčić J, editors. New insights on the Krapina Neandertals. Croatian Natural History Museum: Zagreb. p 5-18.

Holliday TW. 2006. Neanderthals and modern humans: an example of a mammalian syngameon? In: Harvati K, Harrison T, editors. Neanderthals revisited: new approaches and perspectives. Dordrecht: Springer. p 281-298.

Hrdlička A. 1930. The skeletal remains of early man. Smithsonian Miscellaneous Collections, Vol. 83. Washington DC: Smithsonian Institution.

Huxley JS, Haddon AC. 1935. We Europeans: a survey of 'racial' problems. London: Jonathan Cape. 
Jolly C. 2001. A proper study of mankind: analogies from the papionin monkeys and their implications for human evolution. Yrbk Phys Anthropol 44:177-204.

King W. 1864. On the reputed fossil of man of the Neanderthal. Quart J Sci (Lond) 1:88-97.

Klaatsch H, Hauser O. 1910. Homo aurignacensis Hauseri. Ein paläolithischer Skeletfund aus dem untern Aurignacien der Station Combe-Capelle bei Montferrand (Périogord). Praehist Zeitschr 1:273-338.

Krause J, Lalueza-Fox C, Orlando L, Enard W, Green RE, Burbano HA, Hublin J-J, Bertranpetit J, Hänni C, Fortea J, de la Rasilla M, Rosas A, Pääbo S. 2007a. The derived FoxP2 variant of modern humans was shared with Neandertals. Cur Biol 17:1-5.

Krause J, Orlando L, Serre D, Viola B, Prüfer K, Ricards MP, Hublin J-J, Hänni C, Derevianko AP, Pääbo S. 2007b. Neanderthals in central Asia and Siberia. Nature 449:902-904.

Krings M, Stone A, Schmitz RW, Krainitzid H, Stoneking M, Pääbo S. 1997. Neandertal DNA sequences and the origin of modern humans. Cell 90:1-20.

Lieberman DE. 2008. Speculations about the selective basis for modern human cranial form. Evol Anthropol 17:55-68.

Marks J. 1995. Human biodiversity: genes, race, and history. New York: Aldine de Gruyter.

Martínez I, Arsuaga JL, Quam R, Carretero JM, Gracia A, Rodríguez L. 2008. Human hyoid bones from the Middle Pleistocene site of the Sima de los Huesos (Sierra de Atapuerca, Spain). J Hum Evol 54:118-124.

Martinez I, Rosa M, Arsuaga J-L, Jarabo P, Quam R, Lorenzo C, Gracia A, Carretero J-M, Bermudez de Castro J-M, Carbonell E. 2004. Auditory capacities in Middle Pleistocene humans from the Sierra de Atapuerca in Spain. Proc Natl Acad Sci USA 101:9976-9981.

Mayr E. 1942. Systematics and the origin of species. New York: Columbia University Press.

Mayr E. 1963. Animal species and evolution. Cambridge: Belknap Press of Harvard University Press.

Mayr E. 1969. Principles of systematic zoology. New York: McGraw-Hill.

McCown TD, Keith A. 1939. The Stone Age of Mount Carmel: The fossil human remains from the Levalloiso-Mousterian, Vol. 2. Oxford: Clarendon Press.

Montagu MFA, editor. 1964. The concept of race. New York: The Free Press.

Morral N, Nunes V, Casals T, Chillón M, Giménez J, Bertranpetit J, Estivill X. 1993. Microsattelite haplotypes for cystic fibrosis: mutation frameworks and evolutionary tracers. Hum Mol Genet 2:1015-1022.

Pearson K, Davin AG. 1924. On the biometric constants of the human skull. Biometrika 16(3/4):328-363.

Pearson OM. 2008. Statistical and biological definitions of "anatomically modern" humans: Suggestions for a unified approach to modern morphology. Evol Anthropol 17:38-48.

Plagnol V, Wall JD. 2006. Possible ancestral structure in human populations. PLoS Genetics 2:e105.

Quennell M, Quennell CHB. 1945. Everyday life in the Old Stone Age. London: Batsford.

Radovčić J. 1988. Dragutin Gorjanović-Kramberger and Krapina Early Man: The foundation of modern paleoanthropology. Zagreb: Školska knjiga and Hrvatski prirodoslovni muzej.

Ranke J. 1896. Der fossile Mensch und die Menschenrassen. Correspondenzblatt der Deutschen Gesellschaft für Anthropologie, Ethnologie, und Urgeschichte. Archiv für Anthropologie 27:151-156.

Relethford JH. 2008. The human species, 7th ed. Boston: McGraw-Hill.

van Riper AB. 1993. Men among the mammoths: Victorian science and the discovery of human prehistory. Chicago: University of Chicago Press.

Rougier H, Milota S, Rodrigo R, Gherase M, Sarcina L, Moldovan O, Zilhão J, Constantin S, Franciscus RG, Zollikofer CPE, Ponce de León M, Trinkaus E. 2007. Peştera cu Oase 2 and the cranial morphology of early modern Europeans. Proc Natl Acad Sci USA 104:1165-1170.
Sackett JR. 2000. Human antiquity and the Old Stone Age: the nineteenth century background to paleoanthropology. Evol Anthropol 9:37-49.

Sampietro ML, Gilbert MTP, Lao O, Caramelli D, Lari M, Bertranpetit J, Lalueza-Fox C. 2006. Tracking down human contamination in ancient human teeth. Mol Biol Evol 23:18011807.

Schmitz RW. 2006. A romantic valley and a discovery that changed the world. In: Schmitz RW, editor. Neanderthal 1856-2006. Mainz am Rhein: Verlag Philipp von Zabern. p 35-44.

Schoetensack O. 1908 Der Unterkiefer des Homo heidelbergensis aus den Sanden von Mauer bei Heidelberg. Leipzig: W. Engelmann.

Schwalbe G. 1901. Der Neanderthalschädel. Bonner Jahrbücher 106:1-72

Schwalbe G. 1906 Studien zur Vorgeschichte des Menschen. I. Zur Frage der Abstammung des Menschen. Stuttgart: Schweizerbartsche Verlagsbuchhandlung. p 10-80.

Sergi S. 1953. Morphological position of the "Prophaneranthropi" (Swanscombe and Fontéchevade). In: Howells WW, editor. Ideas on human evolution. Cambridge: Harvard University. p 507-520. (Reprinted and translated, 1962.)

Soficaru A, Catalin P, Dobos A, Trinkaus E. 2007. The human cranium from the Peştera Cioclovina Uscată;. Romania. Current Anthropology 48:611-619.

Soficaru A, Dobos A, Trinkaus E. 2006. Early modern humans from the Pesstera Muierii. Baia de Fier, Romania. Proc Natl Acad Sci USA 103:17196-17201.

Stefansson H, Helgason A, Steinthorsdottir GTV, Masson G, Bernard J, Baker A, Jonasdottir A, Ingason A, Gudnadottir VG, Desnica N, Hicks A, Gylfason A, Gudbjartsson DF, Jonsdittir GM, Sainz J, Agnarsson K, Birgisdottir B, Ghosh S, Olafsdottir A, Cazier JB, Kristjansson K, Frigge ML, Thorgeirsson TE, Gulcher JR, Kong A, Stefansson K. 2005. A common inversion under selection in Europeans. Nat Genet 37:129-137.

Stolyhwo K. 1908. Homo primigenius appartient-il à une espèce distincte de Homo sapiens? L’Anthropol 19:191-216.

Stolyhwo K. 1937. Les Prénéanderthaloïdes et leurs rapports avec la race de Néanderthal. Bulletin Ethnologique de Musée d'Ethnographie de Ljubljana 10:147-168.

Swed FS, Eisenhart C. 1943. Tables for testing randomness of grouping in a sequence of alternatives. Ann Math Stat 14:66-87.

Szombathy J. 1925. Die diluvialen Menschenreste aus der Fürst-Johanns-Höhle bei Lautsch in Mähren. Die Eiszeit 2:1$34,73-95$.

Tattersall I. 2000. Paleoanthropology: the last half-century. Evol Anthropol 9:2-16.

Tattersall I, Schwartz JH. 2008. The morphological distinctiveness of Homo sapiens and its recognition in the fossil record: clarifying the problem. Evol Anthropol 17:49-54.

Templeton AR. 1998. Human races: a genetic and evolutionary perspective. Am Anthropol 100:632-650.

Templeton AR. 2005. Haplotype trees and modern human origins. Yearbk Phys Anthropol 48:33-59.

Trinkaus E. 2006. Modern human versus Neandertal distinctiveness. Curr Anthropol 47:597-620.

Trinkaus E. 2007. European early modern humans and the fate of the Neandertals. Proc Natl Acad Sci USA 104:7367-7372.

Trinkaus E, Shipman P. 1993. The Neanderthals: changing the image of mankind. New York: Knopf.

Trinkaus E, Milota Ş, Rodrigo R, Mircea G, Moldovan O. 2003. Early modern human cranial remains from the Peştera cu Oase. Romania. J Hum Evol 45:245-253.

Weidenreich F. 1943a. The "Neanderthal Man" and the ancestors of "Homo sapiens". Am Anthropol 45:39-48.

Weidenreich F. 1943b. The skull of Sinanthropus pekinensis: a comparative study of a primitive hominid skull. Palaeontologia Sinica, New Series D, number 10 (whole series number 127).

Weidenreich F. 1946. Generic, specific, and subspecific characters in human evolution. Am J Phys Anthropol 4:413431. 
Weidenreich F. 1947. Are human races in the taxonomic sense "races" or "species"? Am J Phys Anthropol 5:369-371.

Weinert H. 1925. Der Schädel des eiszeitlichen Menschen von Le Moustier. Berlin: Springer.

Wilson EO, Brown WL. 1953. The subspecies concept and its taxonomic application. Syst Zool 2:97-111.

Wolpoff MH, Caspari R. 1996. An unparalleled parallelism. Anthropologie (Brno) 34:215-223.

Wolpoff MH, Caspari R. 1997. Race and human evolution. New York: Simon and Schuster.

Wolpoff MH, Hawks JD, Caspari R. 2000. Multiregional, not multiple origins. Am J Phys Anthropol 112:129-136.

Wolpoff MH, Hawks JD, Frayer DW, Hunley K. 2001. Modern human ancestry at the peripheries: a test of the replacement theory. Science 291:293-297.

Wolpoff MH and Lee Sang-Hee. 2007. Herto and the Neandertals: what can a 160,000-year-old African tell us about European Neandertal evolution? In: Sankhyan AR, Rao VR, editors. Human origins, genome and people of India: genomic, palaeontological and archaeological perspectives. New Delhi: Allied Publishers. p 329-336.

Wolpoff MH, Mannheim B, Mann A, Hawks J, Caspari R, Rosenberg KR, Frayer DW, Gill GW, Clark GA. 2004. Why not the Neandertals? World Archaeol 36:527-546.

Wolpoff MH, Wu Xinzhi, Thorne AG. 1984. Modern Homo sapiens origins: a general theory of hominid evolution involving the fossil evidence from east Asia. In: Smith FH, Spencer F, editors. The origins of modern humans: a world survey of the fossil evidence. New York: Alan R Liss. p 411-483.

Zängl U. 2006. Hermann Schaaffhausen (1816-1893) and the Neanderthal finds of the 19th Century. In: Schmitz RW, editor. Neanderthal 1856-2006. Mainz am Rhein: Verlag Philipp von Zabern. p 45-53.

Zietkiewicz E, Yotova V, Gehl D, Wambach T, Arrieta I, Batzer M, Cole DE, Hechtman P, Kaplan F, Modiano D, Moisan JP, Michalski R, Labuda D. 2003. Haplotypes in the dystrophin DNA segment point to a mosaic origin of modern human diversity. Am J Hum Genet 73:994-1015.

Zilhão J. 2001. Neandertal/modern human interaction in Europe. In: Thacker P, Hays M, editors. Questioning the answers: resolving fundamental problems of the Early Upper Paleolithic. British Archaeological Reports International Series 1005:13-19.

Zilhão J. 2006. Neandertals and moderns mixed, and it matters. Evol Anthropol 15:183-195.

Zilhão J, d'Errico F, Bordes J-G, Lenoble A, Texier J-G, Rigaud J-P. 2006. Analysis of Aurignacian interstratification at the Châtelperronian-type site and implications for the behavioral modernity of Neandertals. Proc Natl Acad Sci USA 103: 12643-12648.

Zilhão J, Trinkaus E, editors. 2002. Portrait of the artist as a child. The Gravettian human skeleton from the Abrigo do Lagar Velho and its archeological context, Vol. 22. Lisbon: Trabalhos de Arqueologia. 